\title{
RAPID PROCEDURES FOR PRENATAL DIAGNOSIS OF COCKAYNE SYNDROME
}

\author{
Kazuhiko KawaI, ${ }^{1}$ Mituo IKenaga, ${ }^{2}$ Hideaki OhtanI, ${ }^{2}$ Ken-ichiro Fukuchi, ${ }^{1}$ \\ Ken-ichi Yamamura, ${ }^{1}$ and Yuichi Kumahara ${ }^{1}$ \\ ${ }^{1}$ Department of Medicine and Geriatrics, Osaka University Medical School, \\ Fukushima-ku, Osaka 553, Japan \\ ${ }^{2}$ Department of Fundamental Radiology, Faculty of Medicine, Osaka \\ University, Kita-ku, Osaka 530, Japan
}

\begin{abstract}
Summary Changes in the rate of semi-conservative DNA synthesis with time after ultraviolet light irradiation were measured with amniotic fluid cells at 6 to 10th subcultures, which were originally derived from the pregnancy with the fetus affected with Cockayne syndrome. The rate of DNA synthesis at $12 \mathrm{hr}$ after ultraviolet exposure relative to that of unirradiated control was much less in the Cockayne amniotic fluid cells than those observed with normal amniotic fluid cells or with fibroblasts from normal donors. These results suggest that by measuring the rate of DNA synthesis prenatal diagnosis of Cockayne syndrome may be accomplished within 3 to 4 weeks, in contrast to the actual length of time, 5 weeks, required for the prenatal diagnosis of this syndrome by measuring colony forming ability of ultraviolet irradiated cells.
\end{abstract}

\section{INTRODUCTION}

Cockayne syndrome (CS) is a rare autosomal recessive disorder characterized by dwarfism, retinal atrophy, gross mental retardation and skin hypersensitivity to sunlight (Cockayne, 1936). Cultured skin fibroblasts from CS patients have been shown to be more sensitive to ultraviolet light (UV) than those from normal donors, in terms of colony forming ability (Schmickel et al., 1977) and of cellular capacity to synthesize DNA at long time (more than $6 \mathrm{hr}$ ) after UV irradiation (Lehmann et al., 1979; Ikenaga et al., 1981).

Recently, we have succeeded in prenatal diagnosis of this syndrome by assaying colonies of UV-irradiated amniotic fluid (AF) cells, though at the expense of long length of time, 5 weeks, required for the diagnosis (Sugita et al., 1982). In order to shorten the time needed for analysis, we have measured in the present study the rate of DNA synthesis by three different methods in UV-irradiated AF cells derived from 
the pregnancy with the affected fetus mentioned above. The results suggest that it may be possible to detect the affected fetus prenatally within 25 days by measuring the rate of DNA synthesis with use of liquid scintillation counter or rapid autoradiography.

\section{MATERIALS AND METHODS}

\section{Cell strains}

The AF cells from the pregnancy with the fetus, which had been diagnosed prenatally as being affected with CS by Sugita et al. (1982), have been frozen stored under liquid nitrogen at 4th passage. They were thawed, subcultured twice and then used for the experiments. These cells will be referred as CS AF cells hereafter. Culture of normal AF cells was initiated in our laboratory from amniotic fluid obtained from a pregnancy at risk for Down's syndrome (kindly provided by Dr. Suehara, Department of Obstetrics and Gynecology, Osaka University Medical School). The normal AF cells were used at 6 to 10 passages in order to match their morphological types with those of CS AF cells. CS fibroblast strain, CS20S, was derived from the lung of the aborted fetus mentioned above (Sugita et al., 1982). Normal skin fibroblasts, NHKK and N140S, were derived from two normal individuals (Tanaka et al., 1981).

\section{Culture media}

Unless otherwise specified, the culture medium used was Eagle's Minimum Essential Medium (MEM, Research Foundation for Microbial Diseases, Osaka University) supplemented with $2 \%$ of $50 \mathrm{X}$-essential amino acid, $1 \%$ of $100 \mathrm{X}$-nonessential amino acids and of 100X-vitamines (Flow Lab.). The modified MEM was supplemented with $20 \%(\mathrm{v} / \mathrm{v})$ fetal bovine serum (Flow Lab. or Microbiological Associates) for growing AF cells or with $10 \%$ serum for fibroblasts. In some parts of the experiments (Method A, described later), Dulbecco's MEM (powder, Flow Lab.) was used to label the cells with radioactive isotopes. All cultures were maintained at $37^{\circ} \mathrm{C}$ under humidified $5 \%$ (for Eagle's MEM) or $10 \%$ (for Dulbecco's MEM) $\mathrm{CO}_{2}$ atmosphere.

\section{Semi-conservative DNA synthesis after $U V$}

Method A. Liquid scintillation counting of incorporated radioisotopes. The method described by Lehmann et al. (1979) was used with minor modifications mentioned below. Both normal and CS AF cells were used at $6 \mathrm{th}$ passage, where cultures were consisted of approximately equal amounts of fibroblast-like cells and type II Epitheloid cells (Van der Veer et al., 1978). Cells were seeded in twelve $6 \mathrm{~cm}$ Corning culture dishes $\left(10^{5}\right.$ cells/dish) and incubated over night with $4 \mathrm{ml}$ each of Dulbecco's medium. In the next day, cells were labeled for $24 \mathrm{hr}$ with $0.05 \mu \mathrm{Ci} / \mathrm{ml}$ of [ $\left.{ }^{14} \mathrm{C}\right]$ thymidine $\left(\left[{ }^{14} \mathrm{C}\right] \mathrm{TdR}, 55 \mathrm{Ci} / \mathrm{mmol}\right.$, The Radiochemical Centre, Amersham). On the third 
day, one-half of the dishes were irradiated with $8 \mathrm{~J} / \mathrm{m}^{2}$ of $254 \mathrm{~nm}$ UV from a germicidal lamp (Toshiba) and further incubated with fresh non-radioactive medium. At various times during the subsequent $24 \mathrm{hr}$ post-UV incubation, two dish (one control and one UV-irradiated) of cells were labeled for $60 \mathrm{~min}$ with $10 \mu \mathrm{Ci} / \mathrm{ml}$ of $\left[{ }^{3} \mathrm{H}\right] \mathrm{TdR}(20 \mathrm{Ci} / \mathrm{mmol}$, The Radiochemical Centre). Then, the cells were washed with phosphate buffered saline (PBS) and collected in $0.3 \mathrm{ml}$ of $0.2 \mathrm{M} \mathrm{NaOH}$ by scraping off with a rubber policeman. Duplicate $0.1 \mathrm{ml}$ samples were spotted onto Whatman 3MM paper discs. They were washed with $5 \%$ trichloroacetic acid, ethanol, and dried. Acid-insoluble radioactivities were counted by liquid scintillation counter.

Method B. Autoradiographic measurement of DNA synthesis. The method used was essentially the same as those described previously (lkenaga et al., 1981; Tanaka et al., 1982). AF cells used were at 8 to 9 passages, where majority of cells showed fibroblast-like morphology. Exponentially growing cells were seeded in twelve $35 \mathrm{~mm}$ culture dishes $\left(10^{5}\right.$ cells/dish), each contained 3 coverslips ( $15 \mathrm{~mm}$ in diameter). About $24 \mathrm{hr}$ later, cells in 6 dishes were irradiated with $12 \mathrm{~J} / \mathrm{m}^{2} \mathrm{UV}$ and further incubated with fresh culture medium. At various times after $U V$, two dishes of cells, UV-irradiated and non-irradiated, were pulse-labeled for $15 \mathrm{~min}$ with 0.3 $\mu \mathrm{Ci} / \mathrm{ml}$ of $\left[{ }^{3} \mathrm{H}\right] \mathrm{TdR}(5 \mathrm{Ci} / \mathrm{mmol})$. Immediately after labeling, the cells on coverslips were washed three times with PBS and fixed with methanol. Samples were dipped into Sakura NR-M2 emulsion (Konishiroku), exposed for 14 days at $4^{\circ} \mathrm{C}$, and processed in the usual manner. In the autoradiographic measurements, the silver grains on nuclei were counted in 50 consecutive labeled nuclei. A nucleus having more than 3 grains was considered labeled.

Method C. The procedures employed were the same with those of Method B, except for the following changes in order to shorten the time required for the autoradiographic exposure. Cells were pulse-labeled for $30 \mathrm{~min}$ with a high concentration of $\left[{ }^{3} \mathrm{H}\right] \mathrm{TdR}, 5 \mu \mathrm{Ci} / \mathrm{ml}(24 \mathrm{Ci} / \mathrm{mmol})$. In this case the samples were developed after 3 days exposure at $4^{\circ} \mathrm{C}$.

\section{RESULTS}

Figure 1 shows changes in the rate of semi-conservative DNA synthesis in CS and normal cells at various times after UV, as measured by liquid scintillation counting of incorporated ${ }^{3} \mathrm{H}$-radioactivities (Method $\mathrm{A}$ ). The cells were prelabeled with $\left[{ }^{14} \mathrm{C}\right] \mathrm{TdR}$, so that the ratio of ${ }^{3} \mathrm{H}$ to ${ }^{14} \mathrm{C}$ counts gives a measure of the average rate of DNA synthesis in the cell population (Lehmann et al., 1979). The rates of DNA synthesis in CS and normal fibroblasts (Fig. 1, triangles) were reduced immediately after UV to about $60 \%$ of the unirradiated controls, and continued to decrease for at least $2 \mathrm{hr}$. In normal fibroblasts, recovery was initiated at around $4 \mathrm{hr}$, and reached a maximum level about $80 \%$ of the unirradiated cells at $12 \mathrm{hr}$ after UV. By contrast, CS fibroblasts did not show such recovery during the $24 \mathrm{hr}$ incubation. 


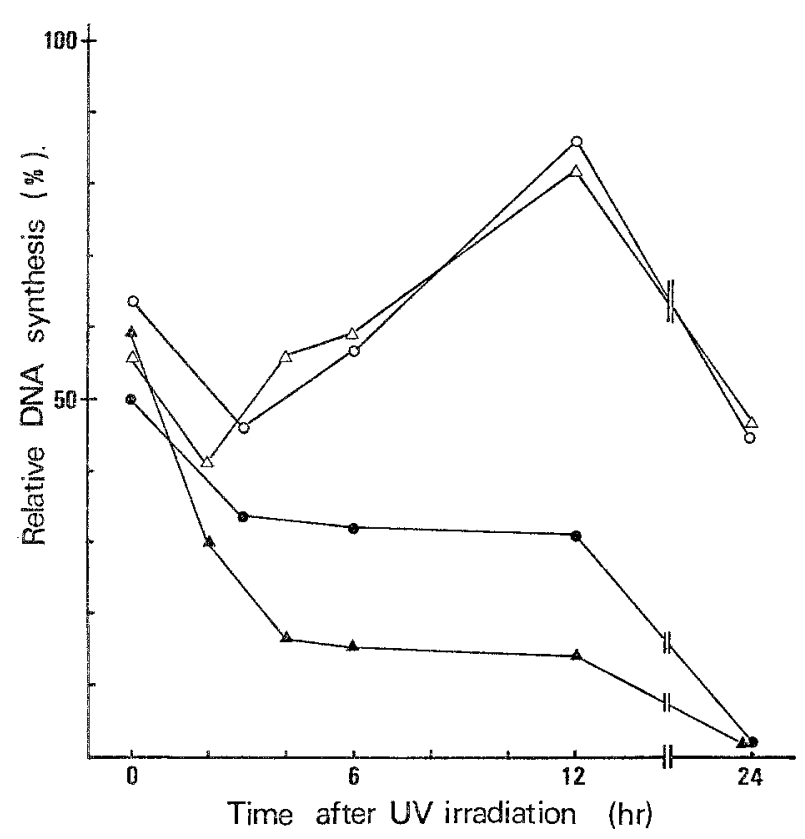

Fig. 1. Relative rate of DNA synthesis at different times after UV irradiation. Cells prelabeled with $\left[{ }^{14} \mathrm{C}\right] \mathrm{TdR}$ were either not irradiated or irradiated with $8 \mathrm{~J} / \mathrm{m}^{2}$ of UV and incubated. At various times after UV, the cells were pulse-labeled for $1 \mathrm{hr}$ with $\left[{ }^{\circ} \mathrm{H}\right] \mathrm{TdR}$, and the acid-inscluble radioactivity was determined by a liquid scintillation counter. Ordinate shows ${ }^{3} \mathrm{H} /{ }^{14} \mathrm{C}$ ratio in the irradiated cells to that in the unirradiated cells. Normal AF cells (O), CS AF cells ( ) ; normal fibroblasts N140S $(\triangle)$, CS fibroblasts CS20S $(\Delta)$.

These results confirmed the previous findings with CS skin fibroblasts (Lehmann et al., 1979; Ikenaga et al., 1981). In AF cells similar patterns of DNA synthetic rate were also observed; marked recovery in normal AF cells at $12 \mathrm{hr}$ and its complete absence in CS AF cells (circles in Fig. 1). The reduction in DNA synthesis at 6 to $12 \mathrm{hr}$ after UV was more evident in CS fibroblasts than in CS AF cells, though these two cell strains originated from the same fetus. This agrees with the lesser UV sensitivity of the same CS AF cell strain compared with the CS fibroblasts (CS20S), as found by measuring their colony forming abilities (Sugita et al., 1982). Nevertheless, since a great differerce exists between CS and normal AF cells in the rate of post-UV DNA synthesis, and since the entire experiments took only 4 days, the Method A appears to be very suitable for rapid prenatal diagnosis of this syndrome.

Figure 2 shows changes in the rate of post-UV DNA synthesis as measured by autoradiography (Method B). Both with fibroblasts (Fig. 2a) and AF cells (Fig. 2b), the results were essentially similar to those obtained by Method A; a marked recovery of DNA synthetic in normal cells at $12 \mathrm{hr}$ after UV and its absence in CS cells. This indicates that the Method B can be applied, in principle, to prenatal 


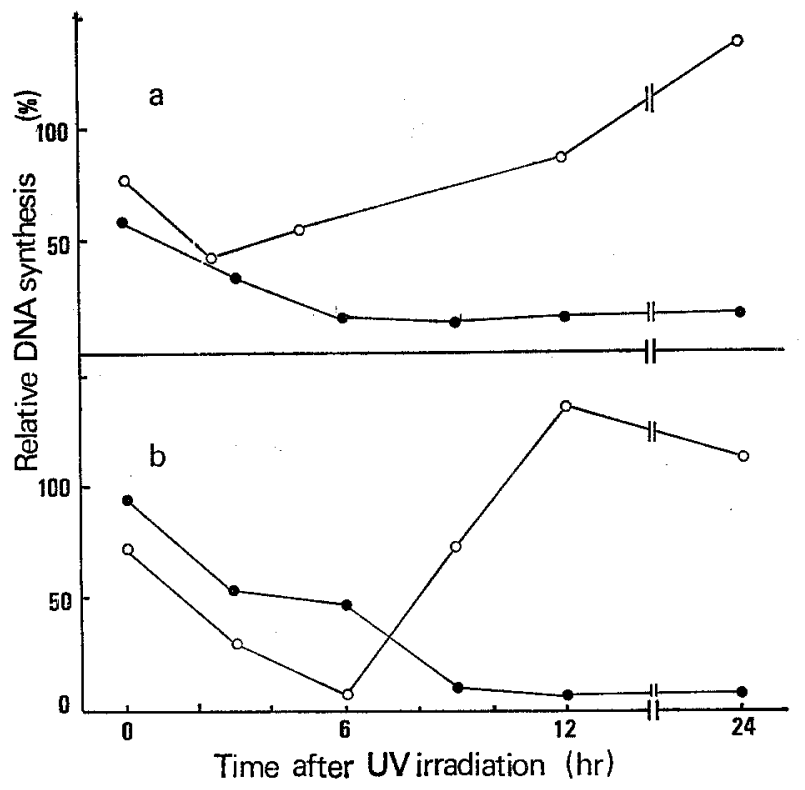

Fig. 2. Rates of DNA synthesis in normal and CS cells during post-UV incubation. Cells growing on coverslips were irradiated with $12 \mathrm{~J} / \mathrm{m}^{2}$ of UV, and incubated for up to $24 \mathrm{hr}$. At the time indicated, the cells were pulse-labeled with $\left[{ }^{3} \mathrm{H}\right] \mathrm{TdR}$, and the rate of DNA synthesis was determined by counting the number of grains in labeled nuclei on the coverslips. The rate is plotted as a percentage of unirradiated cells pulse-labeled at the same time after UV. (a) Fibroblasts: normal, NHKK

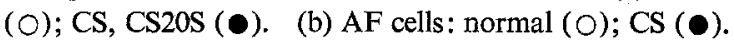

diagnosis of CS. However, it took about 3 weeks to go through entire experimental procedures, from seeding of cells on coverslips to the completion of grain counting.

To finish the experiments more rapidly, cells were pulse-labeled in Method C with 17 times higher concentration of $\left[{ }^{3} \mathrm{H}\right] \mathrm{TdR}(5 \mu \mathrm{Ci} / \mathrm{ml})$ than that used in the Method B, and the labeling period was doubled $(30 \mathrm{~min})$. In addition, specific radioactivity of $\left[{ }^{3} \mathrm{H}\right] \mathrm{TdR}$ used in Method $\mathrm{C}(24 \mathrm{Ci} / \mathrm{mmol})$ was about 5 times higher than that in Method B. By raising the effective dose of $\left[{ }^{3} \mathrm{H}\right] \mathrm{TdR}$ more than 100 times $(17 \times 2 \times 5)$ in such a way, we could observe many grains per nucleus only after 3 days exposure of the autoradiographic samples, which were enough for quantitative analysis (Table 1). As seen in the table, the rate of DNA synthesis in normal AF cells recovered to $71 \%$ of the unirradiated control at $12 \mathrm{hr}$ after $\mathrm{UV}$, whereas it remained suppressed in CS AF cells; only $13 \%$ of the unirradiated cells. The whole experimental procedures took a week by Method C. This clearly shows that the Method $\mathrm{C}$ is also suitable for rapid prenatal diagnosis of CS. 


\section{DISCUSSION}

Recently, we have firstly succeeded in prenatal diagnosis of CS by assaying colony forming ability of UV-irradiated AF cells (Sugita et al., 1982). The main obstacle to the diagnosis was the length of time required; 3 weeks for growing large amount of AF cells and additional 2 weeks for colony assay.

The present measurements of the rate of post-UV DNA synthesis by liquid scintillation counting or by autoradiography revealed that these methods are more practicable than colony assay, because of their rapidity as discussed below. With regard to the time required for experimental analyses, Method A (liquid scintillation counting) took only 4 days and Method $\mathrm{C}$ (autoradiography) 7 days. These lengths of time were one-half or less than that needed for colony assay ( 2 weeks). The number of AF cells used in the present study was $1.2 \times 10^{6}$ both with Method A and C. In the actual case of prenatal diagnosis, however, measurement of DNA synthesis only at two different post-UV incubation period, that is, immediately and $12 \mathrm{hr}$ after UV, should give necessary informations about the recovery pattern in DNA

Table 1. The rate of DNA synthesis at $12 \mathrm{hr}$ after UV irradiation in CS and normal AF cells. ${ }^{\mathrm{a}}$

\begin{tabular}{lccc}
\hline \multirow{2}{*}{ AF cells } & \multicolumn{2}{c}{ Number of grains per nucleus (mean \pm SD) } \\
\cline { 2 - 4 } & UV-irradiated & Unirradiated & Ratio $(\%)^{b}$ \\
\hline Normal & $53.6 \pm 13.8$ & $75.9 \pm 21.4$ & 70.6 \\
CS & $10.9 \pm 3.8$ & $85.4 \pm 20.0$ & 12.8
\end{tabular}

a The rate of DNA synthesis at $12 \mathrm{hr}$ after $12 \mathrm{~J} / \mathrm{m}^{2}$ of UV was determined by counting the number of grains in labeled nuclei following the Method $\mathrm{C}$ (see text for detail). b The mean number of grains per nucleus of UV-irradiated cells relative to that of unirradiated control.

Table 2. Comparison of different methods for prenatal diagnosis of CS.

\begin{tabular}{lcccccc}
\hline Method & $\begin{array}{c}\text { I. Number of } \\
\text { cells needed } \\
\text { for analysis }\end{array}$ & $\begin{array}{c}\text { II. Incuba- } \\
\text { tion period } \\
\text { to prepare } \\
\text { the cells } \\
\text { (days) }\end{array}$ & $\begin{array}{c}\text { III. Time } \\
\text { needed for } \\
\text { experiment } \\
\text { (days) }\end{array}$ & $\begin{array}{c}\text { IV. Time } \\
\text { required for } \\
\text { diagnosis } \\
\text { (days) }\end{array}$ & $\begin{array}{c}\text { V. Experi- } \\
\text { mental } \\
\text { feasibility }\end{array}$ & Reference \\
\hline Method A & $5 \times 10^{5}$ & 21 & 4 & 25 & easy & This paper \\
Method B & $10^{5}$ & 14 & 21 & 35 & laborious & This paper \\
Method C & $10^{5}$ & 14 & 7 & 21 & laborious & This paper \\
Colony assay & $5 \times 10^{5}$ & 21 & 14 & 35 & easyd & Sugita et al. \\
\end{tabular}

a Estimated for Methods $\mathrm{A}, \mathrm{B}$ and $\mathrm{C}$, by assuming that the rate of DNA synthesis was measured at 0 and $12 \mathrm{hr}$ after UV irradiation. $\mathrm{b}$ Length of time from amniocentesis to obtain enough number of AF cells indicated in the column I. c Sum of the periods indicated in the columns II and III. a Required some experiences in cell culture. 
synthesis. Then, the number of AF cells can be reduced to less than half of that used in the present experiments. Furthermore, with Method $\mathrm{C}$ counting of grains only on 50 nuclei was satisfactory to compare the rate of DNA synthesis between CS and normal cells, although there were huge numbers of cells in S-phase (several thousands of cells) per coverslip. Therefore, the number of AF cells can be further reduced in Method C, so that the time spent for growth of AF cells may be considerably shortened.

Table 2 summarizes all these informations to make comparison among the different experimental methods for prenatal diagnosis of CS available at present. We recommend both Methods $\mathrm{A}$ and $\mathrm{C}$ with following comments; Method $\mathrm{C}$ is fastest but somewhat laborious, and Method $\mathrm{A}$ is easy to do but takes a little more time than Method C.

Another minor problem in the prenatal diagnosis by colony assay was the fact that CS AF cells were more resistant to UV than CS fibroblasts, hence the difference in UV sensitivities between CS and normal AF cells was smaller than that between CS and normal fibroblasts (Sugita et al., 1982). Such an intermediate UV sensitivity of CS AF cells was also observed in the present study by using Method A (Fig. 1). Since this was not observed with fibroblast-like AF cells at later passages (Fig. 2b), lesser UV sensitivity of CS AF cells seems to be inherent in AF cells of Epitheloid or spindle-shaped morphology used in experiments with Method A and in the previous study. Nevertheless, a great difference in DNA synthesis between CS and normal AF cells can be observed by choosing appropriate doses of UV (8 to $\left.12 \mathrm{~J} / \mathrm{m}^{2}\right)$.

Acknowledgment This work was supported by a Grant-in-Aid for scientific research from the Japanese Ministry of Education, Science and Culture, and by a research grant for Life Science from The Institute of Physical and Chemical Research, Japan.

\section{REFERENCES}

Cockayne, E.A. 1936. Dwarfism with retinal atrophy and deafness. Arch. Dis. Child. 11: 1-8.

Ikenaga, M., Inoue, M., Kozuka, T., and Sugita, T. 1981. The recovery of colony-forming ability and the rate of semi-conservative DNA synthesis in ultraviolet-irradiated Cockayne and normal human cells. Mutation Res. 91 : 87-91.

Lehmann, A.R., Kirk-Bell, S., and Mayne, L. 1979. Abnormal kinetics of DNA synthesis in ultraviolet light-irradiated cells from patients with Cockayne's syndrome. Cancer Res. 39: 4237-4241.

Schmickel, R.E., Chu, E.H.Y., Trosko, J.E., and Chang, C.C. 1977. Cockayne's syndrome: A cellular sensitivity to ultraviolet light. Pediatrics 60: 135-139.

Sugita, T., Ikenaga, M., Suehara, N., Kozuka, T., Furuyama, J., and Yabuuchi, H. 1982. Prenatal diagnosis of Cockayne syndrome using assay of colony-forming ability in ultraviolet light irradiated cells. Clinical Genet. 22: 137-142.

Tanaka, K., Kawai, K., Kumahara, Y., Ikenaga, M., and Okada, Y. 1981. Genetic complementation groups in Cockayne syndrome. Somatic Cell Genet. 4: 445-455.

Van der Veer, E., Kleijer, W.J., Josselin de Jong, J.E. de, and Galjaard, H. 1978. Lysosomal enzyme activities in different types of amniotic fluid cells measured by microchemical methods, combined with interference microscopy. Hum. Genet. 40: 285-292. 